\title{
KONSEP PENDIDIKAN ISLAM DALAM PERSPEKTIF AL-QUR'AN SURAH LUQMAN AYAT 12-19
}

\author{
Fitriana* \\ Fitrifirda99@gmail.com \\ *Dosen Magister Pendidikan Agama Islam, Universitas Muhammadiyah Tangerang
}

\begin{abstract}
Islamic education is essentially oriented towards religious and worldly goals, namely to form a generation of robbani who are obedient to the laws of God, and are able to face all forms of life challenges that exist, so that their lives become benefits for themselves and their environment. which is always appropriate for every age and place, provides guidance and direction in all areas of life in general, as well as in the principles and concepts in the field of education in particular. Among them as contained in the luqman chapter 12-19 which gives details of the basic concept of Islamic education as a whole; includes aqeedah, sharia and morality.
\end{abstract}

Keywords: Concept, Islamic Education, Al-Qur'an, Surah Luqman Verses 12-19.

\section{A. PENDAHULUAN}

Pendidikan islam merupakan proses trans-internalisasi pengetahuan dan nilai islam kepada peserta didik melalui upaya pengajaran, pembiasaan, bimbingan, pengasuhan, pengawasan dan pengembangan potensinya guna mencapai keselarasan dan kesempurnaan hidup di dunia dan akhirat. ${ }^{1}$

Dalam ayat ke-12 surat Luqman dinyatakan Allah telah mengaruniakan hikmah kepada Luqman, sedangkan ayat 13-19 berisi konsep pendidikan yang diwasiatkan Luqman. Berawal dari hal tersebut, di sini saya mencoba mengontekstualisasikan kandungan ayat tersebut dengan kepribadian anak didik guna menumbuhkan kepribadiannya menjadi pribadi yang islami di masa depan.

Sedang kepribadian islami dapat tercermin melalui pengabdian diri kepada Allah SWT, serta hubungan yang baik antar

\footnotetext{
${ }^{1}$ Abdul Mujib dan Jusuf Mudzakir, Ilmu Pendidikan Islam, Jakarta: Kencana Prenada Media, 2006, hlm. 29-28.
}

sesame dengan landasan demi memperoleh ridhaNya, sehingga diperoleh kebahagiaan hidup di dunia maupun akhirat.

Karena tidak sedikit pendidik yang melalaikan tugasnya untuk memberikan bimbingan dan arahan kepada anak-anak didiknya sesuai dengan potensi fitrahnya.

Kajian ini nantinya difokuskan pada konsep pendidikan Islam serta implikasinya yang ada dalam al-Qur'an surat Luqman ayat 12-19 terhadap kepribadian anak didik.

\section{B. PEMBAHASAN}

\section{Pendidikan dalam al-Qur'an}

Pendidikan yang islami dilaksanakan dalam suatu sistem memberikan kemungkinan berprosesnya bagian-bagian menuju ke arah tujuan yang ditetapkan sesuai ajaran Islam.Jalannya proses itu baru bersifat konsisten dan konstan (tetap) bilamana dilandasi dengan pola dasar pendidikan yang mampu menjamin terwujudnya tujuan pendidikan Islam. 
Diantaranya yaitu pendidkan islam yang bertujuan demi terwujudnya generasi yang kokoh dan kuat dalam segala aspeknya,menjadikan peserta didik berguna dan bermanfaat bagi dirinya maupun bagi masyarakat,tercapainya kehidupan yang sempurna (insan kamil) dan menjadi anak yang sholeh.serta menjadi manusia yang berkepribadian islami. $^{2}$

Adapun kandungan al-Qur'an merupakan dasar ideal pendidikan Islam, yang secara garis besarnya dapat dikelompokkan menjadi tiga kelompok yaitu:

Pertama, al-Qur'an mengandung hukum-hukum yang berkaitan atau bersangkutan dengan halal-haram, farāiḍ dan wājibāt (seruan dan perintah yang pasti) baik yang dianjurkan maupun yang dilarang serta hukuman bagi siapa yang melanggarnya.

Kedua, al-Qur'an mengandung halhal yang bersangkutan dengan 'aqīdah atau kepercayaan.

Ketiga, al-Qur'an mengandung halhal yang bersangkutan dengan kisah-kisah dan cerita-cerita zaman lampau, sebagai pelajaran dan i'tibār.

Kategori kedua dan ketiga tersebut di atas, merupakan kandungan al-Qur'an surat Luqman ayat 12-19 yang berisi tentang kisah Luqman.

Dalam kisah tersebut banyak nilainilai pendidikan yang dapat diambil sebagai pelajaran yang masih sangat relevan dan dapat dijadikan rujukan untuk diaplikasikan dalam proses pendidikan dewasa ini, khususnya pendidikan keluarga. Islam memandang, pada hakikatnya manusia sejak lahir membawa sesuai fitrahnya dan beriman, manusia pada dasarnya adalah fitrah (suci). Allah SWT berfirman:
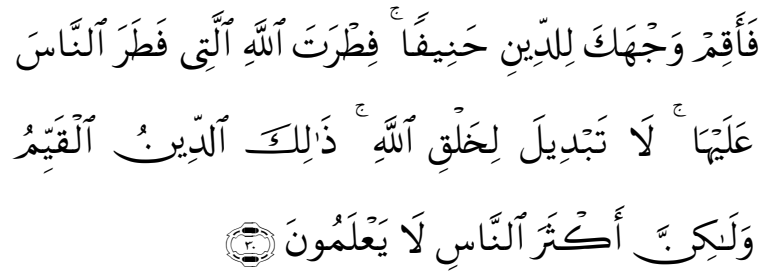

\footnotetext{
${ }^{2}$ Mangun Budianto, Ilmu Pendidikan islam, Yogyakarta: Griya Santri, 2011, hlm. 27.
}

Artinya: "Maka hadapkanlah wajahmu dengan lurus kepada agama Allah; (tetaplah atas) fitrah Allah yang Telah menciptakan manusia menurut fitrah itu. tidak ada perubahan pada fitrah Allah. ${ }^{3}$ (Itulah) agama yang lurus; tetapi kebanyakan manusia tidak mengetahui."

Sebagaimana yang dijelaskan dalam hadis :

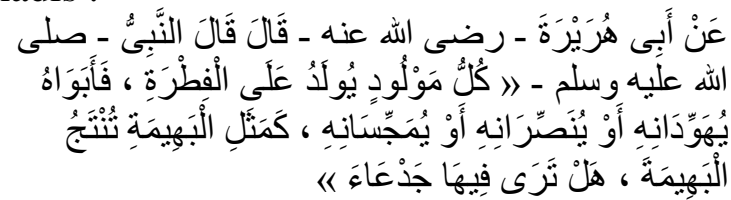

"Tiap orang dilahirkan membawa fitrah; ayah dan ibunyalah yang menjadikannya Yahudi, Nasrani, atau Majusi. Sebagaimana binatang ternak yang melahirkan binatang ternak dengan sempurna. Apakah kalian melihat ada cacat padanya." 4

Hadits tersebut di atas, menjelaskan bahwa dalam proses perkembangannya manusia dipengaruhi oleh faktor lingkungan disamping faktor bawaan yang berupa potensi fitrah tersebut. Dalam proses perkembangannya manusia sebagai subjek yang membangun dan mengembangkan kepribadian diri sesuai dengan khithah kejadiannya. Peletakan tanggung jawab dalam proses penyempurnaan diri pada manusia itu ada dalam al-Qur'an, sehingga dalam proses penyempurnaan jati diri itu, manusia berdiri sebagai subjek yang sadar dan bebas menentukan jalan kehidupannya sendiri, menentukan pilihannya apakah memilih yang bathil (menyimpang dari kecenderungan potensi fitrahnya), atau memilih yang haq atau kebenaran (sesuai dengan kecenderungan potensi fitrahnya), masing-masing memiliki akibat tersendiri.

Dalam penentuan pilihan itulah, maka para pendidk maupun orang tua

\footnotetext{
fitrah Allah: maksudnya ciptaan Allah. manusia diciptakan Allah mempunyai naluri beragama yaitu agama tauhid. kalau ada manusia tidak beragama tauhid, Maka hal itu tidaklah wajar. Karena mereka tidak beragama tauhid itu hanyalah lantaran pengaruh lingkungan.

مَا قِيلَ فِى أَوْلاَدِ المُشْرِكِين juz 5,hal.321.
}

Tadarus Tarbawy. Vol. 1 No. 1 Jan-Jun 2019. 
memiliki peran yang sangat penting. Karena dipundak mereka tanggungjawab memberikan bimbingan dan arahan kepada anak yang dididiknya sesuai dengan potensi fitrahnya, sehingga anak-anak nantinya tumbuh dalam kepribadian Islam.

Namun demikian mendidik anak dan mengajarkan anak bukan merupakan perkara mudah, bukan pekerjaan yang dapat dilakukan secara sembarangan, dan bukan pula hal yang bersifat sampingan. Mendidik dan mengajar anak sama kedudukannya dengan kebutuhan pokok dan kewajiban yang harus dipenuhi oleh setiap muslim. Bahkan mendidik dan mengajarkan anak merupakan tugas yang harus dan mesti dilakukan oleh setiap orang tua, karena perintah mengenainya datang langsung dari Allah swt sebagaimana pengertian yang tersimpulkan dari makna firman-Nya:

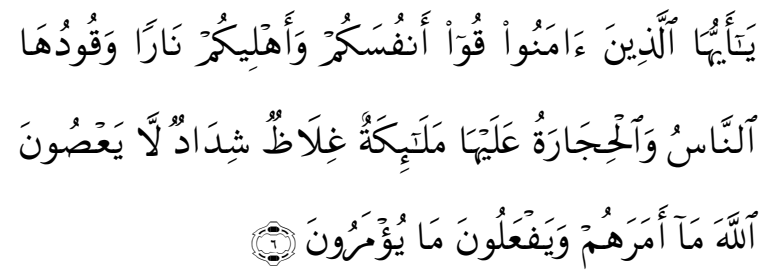

Artinya: " Hai orang-orang yang beriman, peliharalah dirimu dan keluargamu dari api neraka yang bahan bakarnya adalah manusia dan batu; penjaganya malaikat-malaikat yang kasar, keras, dan tidak mendurhakai Allah terhadap apa yang diperintahkan-Nya kepada mereka dan selalu mengerjakan apa yang diperintahkan." At-Tahrim:6.

Sehingga dengan berbekal ajaran alQur'an mengenai konsep mendidik anak khususnya yang ada dalam surah Luqman ayat 12-19, maka para orang tua dan pendidik menjadi paham bagaimana seharusnya mengantarkan anak-anak menuju gerbang keselamatan dunia dan akherat. Apalagi para orang tua menjadi termotivasi oleh asset anak-anak mereka kelak yang membanggakan memakaikan mahkota surga di akherat berkat kesholihan dan ketaqwaan anak-anak mereka kepada allah SWT di dunia.

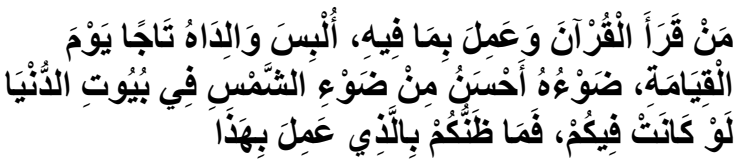

"Barangsiapa yang membaca Al Qur'an, lalu mengamalkan isinya, niscaya ia akan memakaikan mahkota kepada kedua orang tuanya pada hari kiamat, yang cahayanya lebih bagus dari cahaya matahari di dunia, yang menyinari rumah kalian. Maka bagaimana pendapat kalian terhadap orang yang mengamalkan hal tersebut.",

\section{Sosok Luqman al-Hakim}

Al-Hâfizh Ibnu Katsîr rahimahullah menjelaskan, bahwa para ulama salaf berbeda pendapat mengenai Luqman, apakah ia seorang nabi atau hamba sholih tanpa wahyu kenabian?.Kebanyakan berpendapat bahwa ianya hamba allah yang sholih tanpa wahyu kenabian, dan inilah pendapat jumhur. Bahwa Luqman adalah seorang yang taat, shâlih, dan bijaksana, yang telah dikaruniakan oleh Allah Subhanahu wa Ta'ala berbagai keutamaan, berupa kecerdasan akal, kedalaman pemahaman terhadap Islam, sifat pendiam dan tenang, serta hikmah dalam berkatakata. $^{6}$

Menurut Imam Baidhawi dan anNasafi disebutkan bahwa Luqman adalah salah satu anak dari Azar, saudara sepupu Nabi Ayyub. Ia hidup semasa Nabi Dawud dan pernah menjadi seorang mufti sebelum diutusnya Nabi Dawud sebagai rasul. Lebih lanjut, Baidhawi menyebutkan berdasarkan pendapat mayoritas ulama, Luqman bukanlah seorang nabi melainkan hanya seorang hakim.

Dari beberapa pendapat di atas, mayoritas berpendapat bahwa Luqman alHakim adalah hamba Allah yang selalu

\footnotetext{
${ }^{5}$ Almustadrak ala shahhihain, kitab فضائل القرآن juz 2 , hal 236

${ }^{6}$ Tafsir ibnu katsir juz 6, hal 333,tafsir thobari juz 20, hal 134, zadul masir,juz 5, hal 105.

${ }^{7}$ Tafsir baidhawi juz 1, hal 346.tafsir annasafi,juz 3, hal 282. Menurut ibnu katsir luqman yang dimaksud adalah قمان بن عنقاء بن dan anaknya bernama tsaran menurut pendapat suhaili,thobari dll.
} 
mendekatkan diri kepada-Nya, seorang pribadi yang arif nan bijak, sehingga kisah keteladannya dalam mendidik anak diabadikan dalam al-Qur'an.

3. Konsep Pendidikan Islam Dalam Perspektif al-Qur'an Surah Luqman, Ayat: 12-19

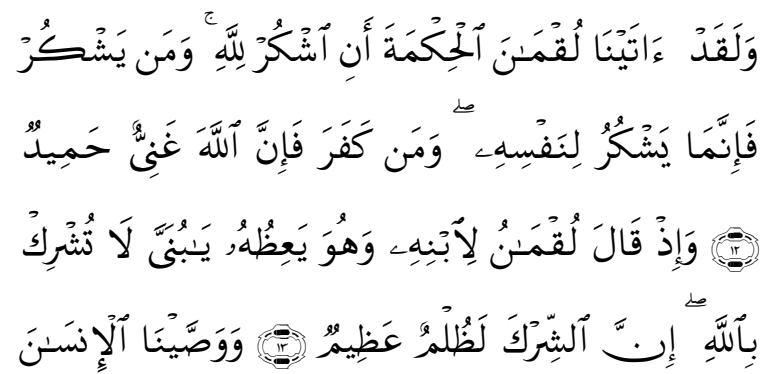

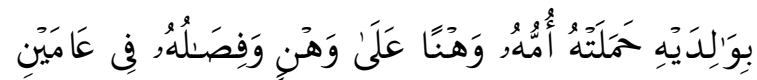

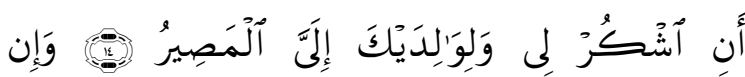

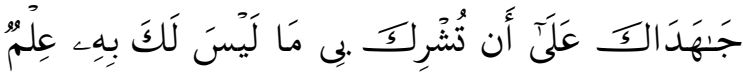

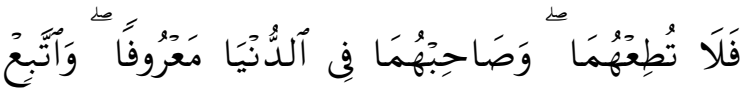

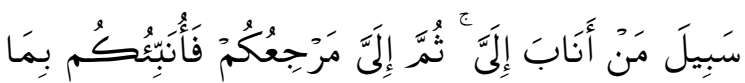

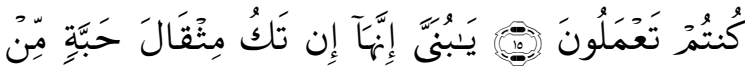

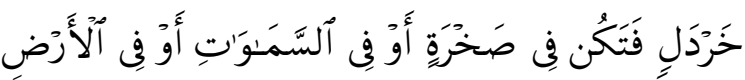

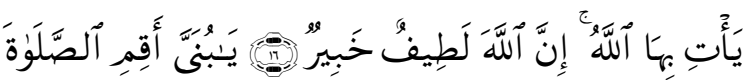

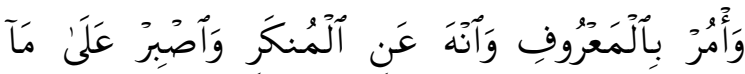

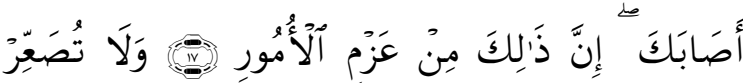

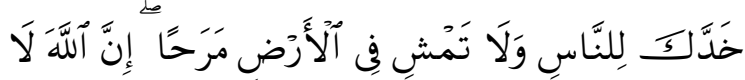

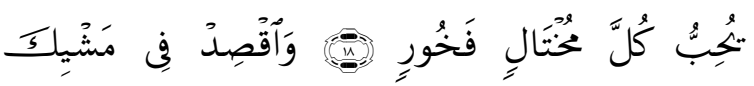

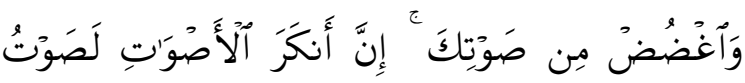

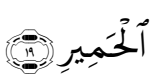

Artinya:

12. Dan Sesungguhnya Telah kami berikan hikmat kepada Luqman, yaitu: "Bersyukurlah kepada Allah. dan barangsiapa yang bersyukur (kepada Allah), Maka Sesungguhnya ia bersyukur untuk dirinya sendiri; dan barangsiapa

Tadarus Tarbawy. Vol. 1 No. 1 Jan-Jun 2019. yang tidak bersyukur, Maka Sesungguhnya Allah Maha Kaya lagi Maha Terpuji".

13. Dan (Ingatlah) ketika Luqman Berkata kepada anaknya, di waktu ia memberi pelajaran kepadanya: "Hai anakku, janganlah kamu mempersekutukan Allah, Sesungguhnya mempersekutukan (Allah) adalah benar-benar kezaliman yang besar". 14. Dan kami perintahkan kepada manusia (berbuat baik) kepada dua orang ibubapanya; ibunya Telah mengandungnya dalam keadaan lemah yang bertambahtambah, dan menyapihnya dalam dua tahun. ${ }^{8}$ bersyukurlah kepadaku dan kepada dua orang ibu bapakmu, Hanya kepadaKulah kembalimu.

15. Dan jika keduanya memaksamu untuk mempersekutukan dengan Aku sesuatu yang tidak ada pengetahuanmu tentang itu, Maka janganlah kamu mengikuti keduanya, dan pergaulilah keduanya di dunia dengan baik, dan ikutilah jalan orang yang kembali kepada-Ku, Kemudian Hanya kepadaKulah kembalimu, Maka Kuberitakan kepadamu apa yang Telah kamu kerjakan.

16. (Luqman berkata): "Hai anakku, Sesungguhnya jika ada (sesuatu perbuatan) seberat biji sawi, dan berada dalam batu atau di langit atau di dalam bumi, niscaya Allah akan mendatangkannya (membalasinya). Sesungguhnya Allah Maha Halus ${ }^{9}$ lagi Maha Mengetahui.

17. Hai anakku, Dirikanlah shalat dan suruhlah (manusia) mengerjakan yang baik dan cegahlah (mereka) dari perbuatan yang mungkar dan Bersabarlah terhadap apa yang menimpa kamu. Sesungguhnya yang demikian itu termasuk hal-hal yang diwajibkan (oleh Allah).

18. Dan janganlah kamu memalingkan mukamu dari manusia (karena sombong) dan janganlah kamu berjalan di muka bumi dengan angkuh. Sesungguhnya Allah tidak menyukai orang-orang yang sombong lagi membanggakan diri.

\footnotetext{
${ }^{8}$ Maksudnya: maksimalnya waktu menyapih ketika anak berusia dua tahun.

${ }^{9}$ Yang dimaksud dengan Allah Maha Halus ialah ilmu Allah itu meliputi segala sesuatu bagaimana pun kecilnya.
} 
19. Dan sederhanalah kamu dalam berjalan ${ }^{10}$ dan lunakkanlah suaramu. Sesungguhnya seburuk-buruk suara ialah suara keledai. ${ }^{11}$

Nilai-nilai pendidikan islam dalam al-Qur'an surat Luqman ayat 12-19 tersebut diatas terangkum dalam tiga asas pendidikan, yaitu; pendidikan aqidah, pendidikan syariah dan pendidikan akhlak.

\section{Pendidikan Aqidah}

Pendidikan aqidah adalah pendidikan yang berusaha mengenalkan, menanamkan serta mengantarkan anak akan nilai-nilai kepercayaan terhadap rukun-rukun iman dan lain sejenisnya. Dari nasihat-nasihat Luqman terhadap anaknya, termasuk dalam kategori pendidikan aqidah terdapat pada ayat 12-19 dari surat Luqman yaitu; larangan menyekutukan Allah dan meyakini adanya tempat kembali.

Penanaman rasa keimanan yang murni sejak anak mulai diusia tingkat Taman Kanak-kanak dan Sekolah Dasar sangatlah penting, sebab naluri anak-anak pada usia ini telah mampu menerima pendidikan keimanan.

Luqman al-Hakim sendiri pun memprioritaskan pendidikan tauhid kepada anaknya. Terbukti pendidikan tauhid telah mendapatkan tempat pertama dari wasiatnya dalam surat Luqman, yakni pada ayat ke-12 dan ke-13. Setelah pada ayat ke12 diperintahkan bersyukur kepada Allah,

${ }^{10}$ Maksudnya: ketika kamu berjalan, janganlah terlampau cepat dan jangan pula terlalu lambat.

${ }^{11}$.Surah luqman : makkiyah berjumlah 34 ayat,dinamakan surah luqman karena isinya yang berupa kisah luqman alhakim yang diketahui memiliki hikmah, atas ma'rifahnya atas keesaan Allah SWT serta penghambaan keatasNYA, dan berkenaan dengan perihal keutamaan akhlak dan adab yang diserukan serta kemungkaran dan kejahatan yang dilarang.surah luqman ini isinya bertema mengenai ketetapan usul akidah yaitu iman kepada allah SWT, kebenaran nubuwwah atau kenabian, dan tetapnya hari berbangkit dan hari akhir. Sebab nuzulnya ayat karena seorang quraisy bertanya kepada Nabi sallallahu alaihi wassalam mengenai kisah luqman dan anaknya serta birrul walidainnya kepada orangtuanya.Tafsir almunir, juz 21, hal 124 yakni Dzat yang wajib ada, maka menurut ayat ke-13 Luqman berkata, "Hai anakku, janganlah kamu mempersekutukan Allah, sesungguhnya mempersekutukan Allah adalah benar-benar kezaliman yang besar."

Syirik dinamakan perbuatan yang zalim, karena perbuatan syirik itu berarti meletakkan sesuatu tidak pada tempatnya, maka ia termasuk dalam kategori dosa besar. Perbuatan tersebut juga berarti menyamakan kedudukan Tuhan dengan makhluk-Nya.

Walaupun pada hakikatnya keimanan atau kekufuran itu tidak mempengaruhi kebesaran-Nya sebagai Raja dari segala Raja, akan tetapi demi kebahagiaan makhluk-makhluk-Nya, Dia pun memerintahkan agar makhluk-makhlukNya supaya beriman kepada-Nya. Inilah salah satu sifat rạ̣mān dan rạ̣im Allah SWT, sebagaimana tertuang dalam firmanNya:

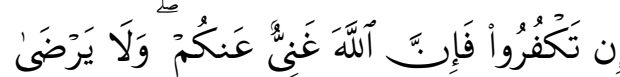

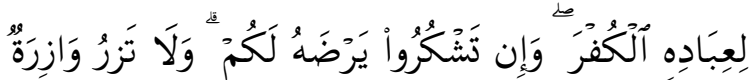

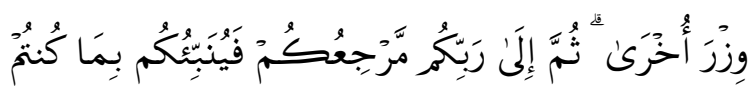

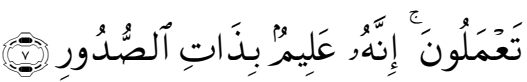

Artinya: " Jika kamu kafir Maka Sesungguhnya Allah tidak memerlukan (iman)mu ${ }^{12}$ dan dia tidak meridhai kekafiran bagi hamba-Nya; dan jika kamu bersyukur, niscaya dia meridhai bagimu kesyukuranmu itu; dan seorang yang berdosa tidak akan memikul dosa orang lain. ${ }^{13}$ Kemudian kepada Tuhanmulah kembalimu lalu dia memberitakan kepadamu apa yang Telah kamu kerjakan. Sesungguhnya dia Maha mengetahui apa yang tersimpan dalam (dada)mu. Surah azZumar:7

Bila direnungkan lebih mendalam ada baiknya setiap individu belajar bersyukur atas berbagai nikmat yang diperolehnya, karena dengan bersyukur diharapkan

\footnotetext{
${ }^{12}$ Maksudnya: beriman atau tidaknya manusia, tidaklah merugikan Tuhan sedikitpun.

${ }^{13}$ Maksudnya: setiap diri memikul dosanya masing-masing.
} 
mereka bisa meminimalisir bahkan bisa terhindar dari perbuatan syirik. Hal ini diperjelas oleh Imam Qurthubi bahwa hakikat bersyukur adalah menaati segala perintah dan menjauhi segala laranganNya.

Dengan demikian, andaikata manusia mampu mensyukuri nikmat dengan sungguh-sungguh secara otomatis mereka tidak akan terperangkap dari perbuatan syirik. Hal ini pun terlihat pada ayat ke-13 di atas, huruf 'ațaf wawu pada awal ayat wa-idzqāla luqmānu...lā tushrik billāh itu ma'tufnya kembali pada ayat anishkur lillāh. Ini mengandung pemahaman bahwa sesungguhnya perbuatan syirik itu tidak akan dilakukan oleh orang-orang yang pandai bersyukur. Apalagi dengan adanya seruan Allah SWT yang mencegah segala bentuk tindakan syirik, maka sebagai makhluk yang berakal sudah semestinya ia tidak melakukan tindakan tersebut.

Larangan perbuatan syirik ini pun terlihat dengan jelas secara redaksio-nal pada ayat ke-13 di atas. Huruf lā nahy pada kata lā tushrik billāh yang dijadikan Tuhan sebagai bentuk pencegahan terhadap tindakan syirik dalam ilmu usul fiqih termasuk memberikan makna $l i$ tahdid,artinya bentuk larang-an secara keras.

Dengan demikian, dapat dipahami bahwa Allah SWT benar-benar mencegah segala bentuk tindakan syirik dan mengatagorikan dosa syirik sebagai perbuatan aniaya yang amat besar (lazulmun 'azìm). Dan hakikat harkat, martabat, kekayaan dan kemegahan manusia di dunia merupakan kamuflase yang semu dan sementara. Sedangkan yang membedakan manusia satu dengan manusia lainnya adalah ketakwaannya di sisi-Nya.

\section{Pendidikan Syariah}

Pendidikan mengenai syariah terkandung dalam ayat ke 17 surah luqman, berisi perintah Allah SWT untuk mendirikanlah shalat dan menyuruh (manusia) mengerjakan yang baik dan mencegah (mereka) dari perbuatan yang

\footnotetext{
${ }^{14}$ Tafsir al-Qurthuby, juz 14,hal 62.
}

mungkar serta bersabar atasnya. Keempat bentuk nasehat inilah yang diberikan Luqman kepada anaknya sebagai bekal agar kokoh jiwanya.

Ayat ke 17 tersebut mendidik anak khususnya dan manusia pada umumnya sebagai pemantapan jiwa.

Dengan demikian, merupakan suatu keniscayaan apabila para orang tua maupun para pendidik mulai mengajarkan nilai-nilai dari pelaksanaan shalat kepada anakanaknya. Baik mengajarkan nilai-nilai yang terkandung dalam bacaan shalat, maupun nilai-nilai dari gerakannya. Minimal memberi pemahaman bahwa shalat bukanlah sekedar ritualitas tanpa makna, melainkan ritualitas bermakna yang dapat mengantarkan anak-anak menjadi pribadi yang sukses, baik di dunia maupun di akhirat. Terlebih apabila penanaman dan pendidikan yang demikian ini diajarkan para orang tua pada saat anak-anak masih berumur 0-12 tahun, niscaya mereka akan senantiasa mengingat, mengamalkan, dan menjadikan batu pijakan butir nasihat orangtuanya tersebut dalam menjalani kehidupan sehari-hari.

Setelah menyuruh anak-anaknya untuk mendidirikan shalat, Luqman alHakim pun pada ayat ke-17 melanjutkan nasihatnya, agar anak-anaknya supaya berbuat kebaikan dan mencegah kemungkaran. kalimat wa'mur bi 'l-ma'rū pada ayat ke-17 ini sebagai ajakan Luqman al-Hakim kepada dirinya sendiri maupun orang lain (anak-anaknya) untuk berbuat kebajikan, seperti budi pekerti yang baik, melakukan pekerjaan yang mulia, membersihkan jiwa dari keburukan. Sedangkan kalimat wanhā 'an al-munkar sebagai ajakannya untuk mencegah kemaksiatan, kejelekan dan kemungkaran baik kepada dirinya sendiri maupun kepada orang lain yang bisa menyebabkan kemurkaan Allah. ${ }^{15}$

Perintah kebajikan dan mencegah berbagai kejelekan merupakan perintah Luqman al-Hakim kepada anak-anaknya pada khususnya dan umat manusia pada

\footnotetext{
${ }^{15}$ Tafsir baidhowi,juz 4,hal 493, tafsir al-munir juz 21, hal 149 .
}

Tadarus Tarbawy. Vol. 1 No. 1 Jan-Jun 2019. 
umumnya.Sehingga, para orang tua maupun para pendidik hendaknya mau mengikuti jejak Luqman al-Hakim yang tidak pernah bosan menyerukan kebaikan dan mencegah segala bentuk kemungkaran di mana pun ia berada. Tentunya sesuai dengan kemampuan dan kapasitasnya masingmasing.

\section{Pendidikan Ahklak}

Pendidikan akhlak adalah pendidikan yang berusaha mengenalkan, menanamkan serta menghayatkan anak akan adanya sistem nilai yang mengatur pola, sikap dan tindakan manusia atas isi bumi. Pola sikap dan tindakan yang dimaksud mencakup pola-pola hubungan dengan Allah, sesama manusia (termasuk dengan dirinya sendiri) dan dengan alam sekitar.

Dengan kata lain, pendidikan akhlak adalah suatu pendidikan yang berusaha mengimplemen-tasikan nilai keimanan seseorang dalam bentuk perilaku. Sebab pendidikan akhlak adalah bagian yang tidak dapat dipisahkan dari pendidikan agama. Sehingga sesuatu, dianggap baik atau buruk oleh seseorang manakala berdasar pada agama.

Adapun nilai pendidikan akhlak yang terdapat dalam nasihat Luqman pada ayat ke-12-19 adalah mensyukuri nikmat Allah SWT. Atas segala nikmat dan karunia Allah, kita harus bersyukur kepadaNya.Nikmat Allah meliputi seluruh hidup, sehingga tidak mungkin bagi kita untuk menghitungnya, mulai dari nikmat yang berhubungan dengan jasmani, rohani, materi dan non materi dengan berbagai ragam. Sebagaimana berfirmanNya dalam al-Qur'an surah Ibrahim ayat 7 :

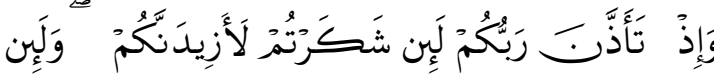

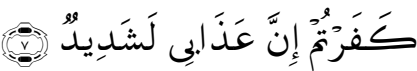

Artinya:" Dan (ingatlah juga),

tatkala Tuhanmu memaklumkan;

"Sesungguhnya jika kamu bersyukur, pasti

kami akan menambah (nikmat) kepadamu, dan jika kamu mengingkari (nikmat-Ku), Maka Sesungguhnya azab-Ku sangat pedih".
Ayat tersebut di atas, menunjukkan betapa pentingnya mensyukuri nikmat. Lebih lanjut dijelaskan andaikata manusia ingin menghitung dan mengidentifikasi nikmat Allah,niscaya ia tidak akan mampu. Sebab nikmat Allah itu sangat besar jumlahnya (tak terhitung) yang terus menerus ada, sedangkan akal manusia itu sangat terbatas dan lemah. Nikmat adalah kesenangan, pemberian atau karunia yang diberikan-Nya kepada manusia. Menurut Imam al-Ghazali nikmat berarti setiap kebaikan yang dapat dirasakan kelezatannya dalam kesenangan hidup, tetapi nikmat yang sejati adalah kesenangan hidup di akhirat. Sedangkan syukur menurut Hamka adalah orang yang mampu mempertinggi dirinya sendiri dengan cara mengenang dan menghargai jasa orang lain.

Orang yang paling berjasa terhadap diri kita adalah kedua orang tua. Sehingga Tuhan pun memerintahkan setiap manusia agar bersyukur kepada keduanya, dan pada perinsipnya yang maha berjasa adalah Allah SWT. Dalam hal ini, Imam al-Qusyairi mengutip dari Syeh Ali Dahaq yang mengatakan bahwa hakikat syukur menurut para ahli ialah pengakuan terhadap nikmat yang diberikanNya yang dibuktikan dengan ketundukannya. Sebagai makhluk yang beradab sudah semestinya manus ia senantiasa bersyukur kepada-Nya, akan tetapi pertanyaannya kemudian adalah bagaimana cara bersyukur yang baik itu bisa terlaksana?

Namun sebelum hal itu dijelaskan perlu disampaikan terlebih dahulu perbedaan antara kata al-syukr (berterima kasih) dan kata al-ḥamd (memuji) agar tidak terjadi kesalahan persepsi dalam memahami kedua kata tersebut. Perbedaan kedua kata tersebut pada dasarnya terletak pada tingkat pelaksanaannya. Kata al-hamd itu terkadang hanya diucapkan dalam lisan saja tanpa adanya tindakan, sedangkan kata al-shukr biasanya sudah mencakup syukur secara lisan dan syukur dengan perbuatan.

Pendidikan akhlak yang mulia terkandung dalam ayat ke 14,mengajarkan kita untuk berbakti kepada kedua orangtua: 
"Dan kami perintahkan kepada manusia (berbuat baik) kepada dua orang ibu- bapanya; ibunya Telah mengandungnya dalam keadaan lemah yang bertambah-tambah, dan menyapihnya dalam dua tahun. bersyukurlah kepadaku dan kepada dua orang ibu bapakmu, Hanya kepada-Kulah kembalimu."

Sebagaimana juga termaktub dalam surah al-Ahqaf ayat 15:

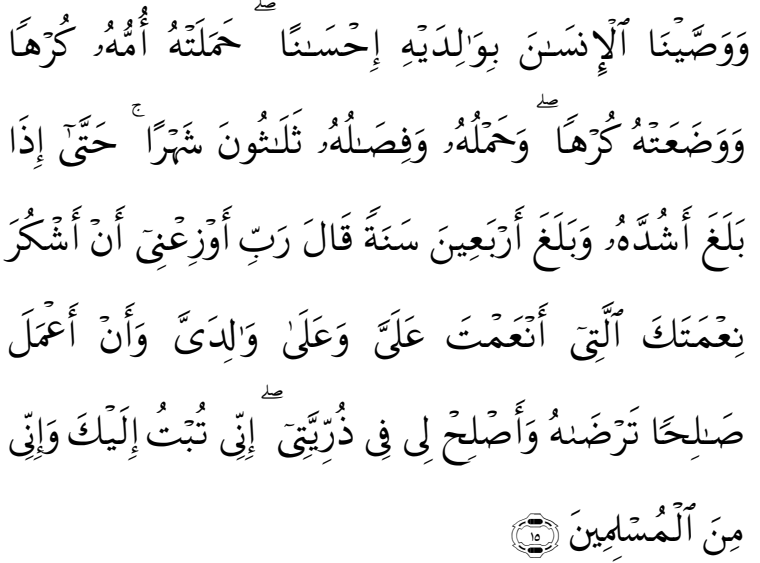

Artinya: "Kami perintahkan kepada manusia supaya berbuat baik kepada dua orang ibu bapaknya, ibunya mengandungnya dengan susah payah, dan melahirkannya dengan susah payah (pula). mengandungnya sampai menyapihnya adalah tiga puluh bulan, sehingga apabila dia Telah dewasa dan umurnya sampai empat puluh tahun ia berdoa: "Ya Tuhanku, tunjukilah Aku untuk mensyukuri nikmat Engkau yang Telah Engkau berikan kepadaku dan kepada ibu bapakku dan supaya Aku dapat berbuat amal yang saleh yang Engkau ridhai; berilah kebaikan kepadaku dengan (memberi kebaikan) kepada anak cucuku. Sesungguhnya Aku bertaubat kepada Engkau dan Sesungguhnya Aku termasuk orang-orang yang berserah diri".

Karena orangtualah yang telah berkorban, bersusah payah,mengandung, melahirkan,memelihara dan mendidik dengan tanpa pamrih penuh kasih sayang dan cinta.

Termasuk pendidikan akhlak juga ialah pada ayat ke 15,bagaimana anak dituntun untuk mengutamakan tauhid beriman kepada Allah. Perbedaan aqidah dengan orangtua tidak menjadikan anak durhaka pada mereka, bahkan dengan adab dan akhlak mulia sang anak senantiasa mengajak orang tuanya kepada agama tauhid hingga Allah yang memberikan hidayahNYA.

Kemudian di ayat ke 16,juga berisikan pengajaran berakhlak mulia, menuntun manusia untuk beramal dengan ikhlas karena Allah semata. Sedang balasan dan ganjaran sekecil apapun akan diberikanNYA.

Selanjutnya pada ayat ke 18 surah luqman mengajarkan bagaimana mendidik anak beretika yang baik, sopan dan beradab.

"Dan janganlah kamu memalingkan mukamu dari manusia (karena sombong) dan janganlah kamu berjalan di muka bumi dengan angkuh. Sesungguhnya Allah tidak menyukai orang-orang yang sombong lagi membanggakan diri."

Sebagaimana terdapat dalam surah al-isra:37

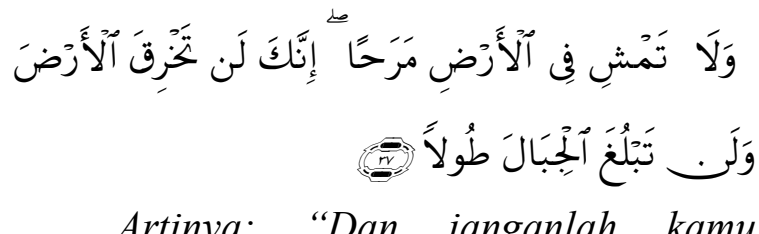

Artinya: "Dan janganlah kamu berjalan di muka bumi Ini dengan sombong, Karena Sesungguhnya kamu sekali-kali tidak dapat menembus bumi dan sekali-kali kamu tidak akan sampai setinggi gunung."

Ajaran yang sama juga terdapat dalam ayat ke 19 surah luqman yaitu berlaku sederhana dalam segala hal,

"Dan sederhanalah kamu dalam berjalan ${ }^{16}$ dan lunakkanlah suaramu. Sesungguhnya seburuk-buruk suara ialah suara keledai." furqan:63

Sebagaimana terdapat dalam surah

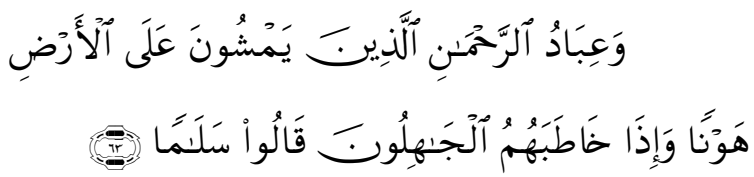

Artinya: "Dan hamba-hamba Tuhan yang Maha Penyayang itu (ialah) orangorang yang berjalan di atas bumi dengan

\footnotetext{
${ }^{16}$ Maksudnya: janganlah terlampau cepat dan jangan pula terlalu lambat ketika kamu berjalan.
} 
rendah hati dan apabila orang-orang jahil menyapa mereka, mereka mengucapkan kata-kata (yang mengandung) keselamatan.

Sehingga anak diajarkan sikap tawadhu dan tidak berlebih-lebihan dalam berprilaku.

\section{Memperhatikan anak balita (bayi lima tahun ) ke atas}

Pada periode ini anak menjadi lebih siap untuk belajar secara teratur. Ia mau menerima pengarahan lebih banyak, dan lebih bisa menyesuaikan diri dengan teman-teman sepermainannya. Dapat kita katakan, pada periode ini anak lebih mengerti dan lebih semangat untuk belajar dan memperoleh ketrampilan-ketrampilan, karenanya ia bisa diarahkan secara langsung. Oleh sebab itu, masa ini termasuk masa yang paling penting dalam pendidikan dan pengarahan anak.

Aspek-aspek terpenting yang perlu diperhatikan oleh para pendidik pada periode ini. Yaitu:

1. Pengenalan Allah (ma'rifatullah) dengan cara yang sederhana.

Pada periode ini dikenalkan kepada anak tentang Allah 'Azza Wajalla dengan cara yang sesuai dengan penger tian dan tingkat pemikirannya. Diajarkan kepadanya:

a. Bahwa Allah Esa, tiada sekutu bagiNya.

b. Bahwa Dialah Pencipta segala sesuatu. Pencipta langit, bumi, manusia, hewan, pohon-pohonan, sungai dan lainlainnya. Pendidik dapat memanfaatkan situasi tertentu untuk bertanya kepada anak, misalnya ketika bejalan-jalan di taman atau padang, tentang siapakah Pencipta air, sungai,bumi,pepohonan dan lain-lainnya, untuk menggugah perhatiannya kepada keagungan Allah.

c. Cinta kepada Allah, dengan ditunjukkan kepadanya nikmat-nikmat yang dikaruniakan Allah untuknya dan untuk keluarganya. Misalnya, anak ditanya: Siapakah yang memberimu pendengaran, penglihatan dan akal? Siapakah yang memberimu kekuatan dan kemampuan untuk bergerak? Siapakah yang memberi rizki dan makanan untukmu dan keluargamu? Demikianlah, ditunjukkan kepadanya nikmat-nikmat yang nyata dan dianjurkan agar cinta dan syukur kepada Allah atas nikmat yang banyak ini. Metode ini disebutkan dalam Al Qur'an, dalam banyak ayat Allah menggugah minat para hamba-Nya agar memperhatikan segala nikmat yang dikaruniakan-Nya, seperti firmanNya:

$\begin{array}{rrr}\text { "Tidakkah } & \text { kamu } & \text { perhatian } \\ \text { sesungguhnya } & \text { Allah } & \text { telah }\end{array}$
menundukkan untuk kepentinganmu apa yang di langit dan apa yang di bumi dan menyempumakan untukmu nikmatnya lahir dan batin..."(Surah Luqman : 20).

"Hai manusia, ingatlah akan nikmat Allah kepadamu Adakah pencipta selain Allah yang dapat memberikan rizki kepadamu dari langit dan bumi...."(Surah Fathir :3).

Dan dengan rahmat-Nya, Dia jadikan untukmu malam dan siang, supaya kamu beristirahat pada malam itu dan supaya kamu mencari sebahagian dari karunia-Nya (pada siang hari) dan agar kamu bersyukur kepadan-Nya." (Surah Al Qashash : 73).

2. Pengajaran sebagian hukum yang jelas dan tentang halal-haram.

Diajarkan kepada anak menutup aurat, berwudhu, hukum-hukum thaharah (bersuci) dan pelaksanaan shalat. Juga dilarang dari hal-hal yang haram, dusta, adu domba,mencuri dan melihat kepada yang diharamkan Allah. Pokoknya, disuruh menetapi syariat Allah sebagaimana orang dewasa dan dicegah dari apa yang dilarang sebagaimana orang dewasa, sehingga anak akan tumbuh demikian dan menjadi terbiasa. Karena bila semenjak kecil anak dibiasakan dengan sesuatu, maka kalau sudah dewasa akan menjadi kebiasaannya.

3. Pengajaran baca Al Qur'an. 
Al Qur'an adalah jalan lurus yang tak mengandung suatu kebatilan apapun. Maka amat baik jika anak dibiasakan membaca $\mathrm{Al} \mathrm{Qu}$ an dengan benar, dan diupayakan semaksimalnya agar menghafal Al Qur'an atau sebagian besar darinya dengan diberi dorongan melalui berbagai cara.

Karena itu, kedua orangtua bendaklah berusaha agar putera puterinya masuk pada salah satu sekolah tahfizh Al Qur'an; kalau tidak bisa, diusahakan masuk pada salah satu halaqah tahfizh. Diriwayatkan Abu Dawud dari M u'adz bin Anas bahwa Nabi shallallahu alaihi wasalam bers abda: "Barang siapa membaca Al-quran dan mengamalkan kandungan isinya, niscaya Allah pada hari kiamat mengenakan kepada keda orang tuanya sebuah mahkota yang cahayanya lebih indah daripada cahaya mataharidi rumah-rumah dunia. Maka apa pendapatmu tentang orang yang mengamalkan hal ini".

4. Pengajaran hak-hak kedua orangtua,

Diajarkan kepada anak untuk bersikap hormat, taat dan berbuat baik kepada kedua orangtua, sehingga terdidik dan terbiasa demikian. Anak sering bersikap durhaka dan melanggar hak-hak orangtua disebabkan karena kurangnya perhatian orangtua dalam mendidik anak dan tidak membiasakannya berbuat kebaikan sejak usia dini.

Firman Allah Ta'ala : 'Dan Tuhanmu telah memerintahkan supaya kamu jangan beribadah kepada selain Dia dan hendaklah kamu berbuat baik pada ibu bapakmu dengan sebaik-baiknya. Jika salah seorang diantara keduanya atau kedua-duanya sampai berumur lanjut dalam pemeliharaanmu, maka sekali-kali janganlah kamu mengatakan kepada keduanya perkataan"ah" dan janganlah kamu membentak mereka dan ucapkanlah kepada mereka perkataan yang mulia. Dan rendahkanlah dirimu terhadap mereka berdua dengan penuh kesanyangan dan ucapkanlah: "Wahai Tuhanku, kasihilah mereka keduanya, sebagaimana mereka berdua telah mendidik aku waktu kecil." (Surah Al-Isra': 23-24).
5. Pengenalan tokoh-tokoh teladan yang agung dalam Islam.

Tokoh teladan kita yang utama yaitu Rasulullah Shallallahu alaihi wasalam, kemudian para sahabat yang mulia Radhiallahu 'Anhum dan pengikut mereka dengan baik yang menjadi contoh terindah dalam segala aspek kehidupan. Maka dikenalkan kepada anak tentang mereka, diajarkan sejarah dan kisah mereka supaya meneladani perbuatan agung mereka dan mencontoh sifat baik mereka seperti keberanian, keprajuritan, kejujuran, kesabaran, kemuliaan, keteguhan pada kebenaran dan sifat-sifat lainnya. .

6. Pengajaran etika umum.

Seperti etika mengucapkan salam dan meminta izin, etiket berpakaian, makan dan minum, etiket berbicara dan bergaul dengan orang lain. Juga diajarkan bagaimana bergaul dengan kedua orangtua, sanak famili yang tua, kolega orangtua, gurugurunya, kawan-kawannya dan teman sepermainannya.

Diajarkan pula mengatur kamamya sendiri, menjaga kebersihan rumah, menyusun alat bermain, bagaimana bermain tanpa mengganggu orang lain dan bagaimana bertingkah laku di masjid dan disekolahan. Pegajaran berbagai hal di atas dan juga lainnya pertama-tama harus bersumber kepada Sunnah Rasulullah, lalu peri kehidupan para salaf yang shaleh, kemudian karya tulis para pakar dalam bidang pendidikan dan tata pergaulan.

7. Pengembangan rasa percaya diri dan tanggung jawab dalam diri.

Anak-anak sekarang ini adalah pemimpin di masa depan. Karena itu, harus dipersiapkan dan dilatih mengemban tanggung jawab dan melaksanakan tugas yang nantinya akan mereka lakukan. Hal itu bisa direalisasikan dalam diri anak melalui pembinaan rasa percaya diri, penghargaan jati dirinya, dan diberikan kepada anak kesempatan untuk menyampaikanpendapatnya dan apa yang terbetik dalam pikirannya,serta diberikan kepadanya dorongan agar mengerjakan urusannya sendiri, bahkan ditugasi dengan 
pekejaan rumah tangga yang sesuai untuknya. Maka diajarkan kepada anak bahwa ia bertanggung jawab atas kesalahan yang dilakukannya serta dituntut untuk memperbaiki apa yang telah dirusaknya dan meminta maaf atas kesalahannya.

Perhatikan kisah berikut yang menunjukkan rasa percaya diri: Diriwayatkan oleh Al Hafizh Ibnu Asakir, ketika Abdullah bin Az Zubair sedang bernain-main dengan anak-anak sebayanya, lewatlah khalifah Umar bin Khattab Radhiyallahu 'Anhtr. Maka larilah semua anak karena takut kepada beliau, kecuali Abdullah bin Az Zubair yang masih tinggal di tempat. Lalu Umar menghampirinya dan bertanya kepadanya: "Kenapa kamu tidak lari bersama teman-temanmu,nak?" Dengan berani dan tenang Abdullah menjawab: "Ya Amirul Mu'minin! Aku bukan seorang yang bersalah sehingga harus takut, dan jalan pun tidak sempit sehingga aku harus minggir. Seorang anak jika terdidik untuk percaya diri akan mampu mengemban tanggung jawab yang besar. Sebagaimana putera-putera para sahabat, mereka berusaha sungguhsungguh agar dapat ikut bersama para mujahidin Fisabilillah; sampai salah seorang di antara mereka ada yang menangis karena Rasulullah belum mengizinkannya ikut berperang bersama pasukan, tetapi karena simpati terhadapnya beliau pun mengizinkannya; dan akhimya ia termasuk salah satu syuhada dalam peperangan itu. Rasulullah juga pernah mengangkat Usamah bin Zaid sebagai komandan pasukan yang di antara anggotanya terdapat Abu Bakar dan Umar, sekalipun masih muda belia tetapi ia orang yang tepat untuk jabatan itu. Lalu,di manakah anak-anak kita sekarang ini yang mampu menduduki puncak yang tinggi.

\section{KESIMPULAN DAN SARAN}

Kesimpulan:

1. Konsep pendidikan islam yang terkandung dalam al-Qur'an surat Luqman ayat 12-19 pada dasarnya meliputi tiga asas pendidikan yang fundamental yaitu; pendidikan aqidah, pendidikan syariah, dan pendidikan akhlak.

2. Implikasi konsep pendidikan islam yang terkandung dalam surat Luqman tersebut, menjadikan pembentukan kepribdian yang Islami sebagai salah satu pilihan guna membentengi anak sedini mungkin dari pengaruh lingkungan yang negatif. Pembentukan kepribadian anak pada prinsipnya merupakan proses yang berkelanjutan. Proses tersebut akan lebih baik dan berhasil manakala para orang tua dapat mengkombinasikan dua faktor, yaitu faktor persiapan berfungsi sebagai proses pembentukan kepribadian anak sebelum ia lahir di dunia (prenatal), dan faktor pelaksaan berfungsi sebagai proses pembentukan kepribadian anak setelah ia lahir, melalui pendidikan formal dan pendidikan nonformal.

3. Konsep pendidikan Islam yang terkandung dalam nasihat Luqman al-Hakim ini merupakan konsep pendidikan Islam yang sempurna dan menyeluruh. Dan metode yang dipergunakan pun sangat ideal yaitu dengan keteladanan,nasehat,dan pengawasan.

4. Adapun Konsep - konsep pendidikan islam yang terkandung dalam nasihat Luqman al-Hakim itu adalah bahwasanya anak harus diajarkan secara baik dan benar mengenai keimanan atau akidah tauhid yang berisikan perintah untuk memurnikan peribadatan atau ibadah hanya kepada Allah semata serta penanaman jiwa atau perasaan selalu dalam pengawasan-Nya.Terkandung juga didalamnya mengenai pendidikan ibadah yang merupakan bentuk realisasi dari rukun islam ke2 yaitu perintah mendirikan shalat yang merupakan tiang agama.Kandungan lainnya dalam nasihat Luqman al-Hakim yang 
terkait dengan pendidikan akhlak yaitu perintah untuk berbakti dan taat kepada kedua orang tua, bersabar menghadapi musibah, larangan berlaku sombong, sederhana dalam segala urusan serta anjuran untuk selalu nasihat menasihati dalam kebaikan dan mencegah kemungkaran.

Semua kandungan nasihat yang telah disebutkan di atas merupakan dasar maupun pokok-pokok pendidikan Islam yang jika dijabarkan secara rinci maka akan menyentuh seluruh sisi-sisi bangunan ajaran atau syariat agama Islam yang sempurna. Kesemuanya itu sangat dibutuhkan oleh setiap orang tua atau pendidik maupun penyelenggara pendidikan Islam sebagai bekal anak mengarungi kehidupan demi mengantarkan anak menjadi manusia yang beriman dan bertakwa kepada Tuhan Yang Maha Esa, berakhlak mulia, berilmu dan bertanggungjawab sesuai dengan yang dikehendaki dalam tuntunan AlQur'an dan Hadits.

5. Tugas orang tua dan pendidik yang terangkum dalam surah luqman:

1) menanamkan keimanan dalam jiwa anak

2) mendidik anak agar taat menjalankan syareat agama

3) mendidik anak agar berakhlak yang mulia

4) anak adalah karunia allah sekaligus amanah dariNYA yang harus disyukuri, dididik dan dibina agar menjadi manusia berkepribadian kokoh dan berbudi pekerti mulia.Sedang pembentukan utama pribadi anak ada dalam keluarga.

Saran:

1. Untuk Pendidik

Pada dasarnya pendidikan akhlak mengenai perintah berprilaku mulia dan larangan berprilaku tercela telah nyata dan dijelaskan oleh alQur'an dan as-Sunnah, diantaranya adalah yang terkandung dalam surat Luqman ayat 12-19. Oleh karena itu, disarankan kepada pendidik agar menjadi tauladan bagi anak didik, dengan melakukan perbaikan akhlak dalam menjalani kehidupan.

2. Untuk orang tua

Orang tua sangat berperan dalam pembentukan akhlak seorang anak, diharapkan orang tua mampu meneladani kisah luqman dalam mendidik anak yang sesuai dengan pendidikan akhlak yang terdapat dalam surat Luqman ayat 12-19.. Wallahu'alam bishowab...

\section{DAFTAR PUSTAKA}

Al Hakim an Naisabury, alMustadrak 'ala shohihain,Dar-alKutub al Ilmiah, Beirut, cet-ke1,1411 H.

Abdul Mujib dan Jusuf Mudzakir, Ilmu Pendidikan Islam, Jakarta: Kencana Prenada Media, $2006 \mathrm{M}$.

Al Imam alBukhari, alJami' aShohih alMukhtasor, Dar-Ibn Katsir Yamamah, Beirut, cet-ke 3, 1987 M.

Al-imam alBaidhowi, Tafsir Anwar al Tanzil wa Asrar alTa'wil, DaralFikr,Beirut.

Al-Imam alQurthuby, alJami' li ahkam alqur'an, Dar-aSya'b,Kairo.

Ibnu Jarir al Thobari Abu Ja'far, Tafsir Jami al Bayan 'an Ta'wil ai al Qur'an, Dar-alFikr,Beirut, 1412 H.

Ibnu al Jauzi, Zadul masir fi ilmi al tafsir, dar- alfikr,Beirut,cet ke-1, $1987 \mathrm{M}$.

Ibnu Katsir al Dimasq Abu al Fida, Tafsir al-Qur'an al'Azhim, DaralFikr,Beirut, $1411 \mathrm{H}$.

Mangun Budianto, Ilmu Pendidikan islam, Yogyakarta: Griya Santri, 2011.

Wahbah bin Musthofa alZuhaily, Tafsir alMunir fil Aqidah wal Syariah wal Manhaj,

Dar-alFikr alMua'shir,Dimasq, cet-2,1418 H. 